\title{
Heat stress inhibits proliferation, promotes growth, and induces apoptosis in cultured Lantang swine skeletal muscle satellite cells*
}

\author{
Chun-qi GAO ${ }^{\S 1}$, Yin-ling ZHAO ${ }^{\S 1}$, Hai-chang $\mathrm{LI}^{2}$, Wei-guo SUI ${ }^{1}$, Hui-chao YAN ${ }^{\dagger+1}$, Xiu-qi WANG ${ }^{\dagger 11}$ \\ $\left({ }^{1}\right.$ College of Animal Science, South China Agricultural University / National Engineering Research Center for Breeding Swine Industry / \\ Guangdong Provincial Key Laboratory of Agro-Animal Genomics and Molecular Breeding, Guangzhou 510642, China) \\ ( ${ }^{2}$ Davis Heart \& Lung Research Institute, Wexner Medical Center at the Ohio State University, Columbus, OH 43210, USA) \\ †E-mail: yanhc@scau.edu.cn; xqwang@scau.edu.cn \\ Received Nov. 30, 2014; Revision accepted May 16, 2015; Crosschecked May 25, 2015
}

\begin{abstract}
Proliferation suppression and apoptosis are the prominent characteristics induced by heat stress (HS) in cells, whereas the effects of HS on cell growth (mass accumulation) are unknown. In this study, Lantang swine (an indigenous breed of China) skeletal muscle satellite cells (SCs) were pre-cultured at $37^{\circ} \mathrm{C}$ for $24 \mathrm{~h}$. The HS group was subjected to $\mathrm{HS}$ at $41^{\circ} \mathrm{C}$, while the control group was maintained at $37^{\circ} \mathrm{C}$. Heat shock protein 70 (HSP70) expression and SC size are significantly increased $(P<0.05)$ by HS, but cell proliferation is suppressed $(P<0.05)$ and apoptosis is induced $(P<0.05)$. HS led to a lower percentage of SCs in the G0/G1 phase $(P<0.05)$ together with a higher percentage of SCs in the S phase $(P<0.05)$. However, the percentage of SCs in the G2/M phase was decreased $(P<0.05)$ at $48 \mathrm{~h}$ but then increased $(P<0.05)$ at $72 \mathrm{~h}$ with $\mathrm{HS}$. In addition, the phosphorylation ratios of protein kinase $\mathrm{b}(\mathrm{Akt})$, ribosomal protein $\mathrm{S} 6$ kinase $(\mathrm{S} 6 \mathrm{~K})$, and ribosomal protein $\mathrm{S} 6$ were increased $(P<0.05)$ by HS. Nevertheless, the phosphorylation ratios of the $4 \mathrm{E}$ binding protein 1 and the eukaryotic initiation factor- $4 \mathrm{E}$ were indistinguishable $(P>0.05)$ from those of the control group. The phosphorylation ratio of the mammalian target of rapamycin (mTOR) $\left(\mathrm{Ser}^{2448}\right)$ increased $(P<0.05)$ within $48 \mathrm{~h}$, and apparent differences were abrogated at $72 \mathrm{~h}(P>0.05)$. Moreover, cleaved caspase-3 expression was increased at $72 \mathrm{~h}(P<0.05)$. These findings indicate that HS induces apoptosis and disrupts cell cycle distribution to decrease the number of cells. Additionally, HS can promote SC growth via an activated Akt/mTOR/S6K signaling pathway.
\end{abstract}

Key words: Heat stress, Swine, Cell proliferation, Cell growth, Apoptosis, Akt/mTOR/S6K pathway doi:10.1631/jzus.B1400339 Document code: A CLC number: S811

\section{Introduction}

It has been demonstrated that when cells or organisms are subjected to abnormally high environmental temperatures, they undergo an active heat shock response (Velichko et al., 2013). An increase in

\footnotetext{
${ }^{\ddagger}$ Corresponding authors

$\S$ The two authors contributed equally to this work

* Project supported by the National 948 Program of China (No. 2011-G35), the National Basic Research Program (973) of China (No. 2012CB124704), and the Science and Technology Planning Project of Guangzhou, Guangdong Province, China (Nos. 201510010020 and 201300000035)

(DBD ORCID: Xiu-qi WANG, http://orcid.org/0000-0003-2033-9485

(C) Zhejiang University and Springer-Verlag Berlin Heidelberg 2015
}

heat shock proteins (HSPs) is a well-characterized feature of the heat shock response (Lindquist, 1986), and studies have demonstrated that heat shock protein 70 (HSP70) can be an indicator of heat stress (HS) in different species (Kamanga-Sollo et al., 2011; Sirotkin and Bauer, 2011). It is well established that the effects of HS vary depending on the strength and duration of stress exposure (Li S.Q. et al., 2012; Rezai Rad et al., 2013).

In addition to the decrease in growth rate, feed intake, and reproduction (Pearce et al., 2013; Morales et al., 2014), studies in many species have indicated that muscle growth is also affected by HS-related alterations in muscle physiology (Liu et al., 2009; 
Locke and Celotti, 2014). Because muscle fiber number is fixed before birth, the rate and extent of postnatal muscle growth is determined by satellite cells (SCs) (Millward et al., 1976). Consequently, the effects of HS on the proliferation, growth, and apoptosis of skeletal muscle SCs could play a crucial role in determining the impact of HS on muscle physiology.

Cell number is dependent on a balance between cell proliferation and cell death, whereas cell size is dependent on cell growth (Tumaneng et al., 2012). Cell fate is reasonable to speculate that HS may influence cell proliferation and apoptosis. Studies have reported that HS can induce cell division arrest, and exposure of cells to acute or chronic HS induces cell death via apoptosis, necrosis, or autophagy (Kühl and Rensing, 2000; Li Y. et al., 2012; Zhang et al., 2012). A number of studies have reported the effects of HS on cell number. However, to our knowledge, there is little known on effects of HS on cell growth. The mammalian target of rapamycin (mTOR) pathway has been reported to regulate cell growth and proliferation via its two well-established substrates, i.e. ribosomal protein S6 kinases (S6Ks) and eukaryotic translation initiation factor 4E-binding protein 1 (4EBP1), respectively (Dowling et al., 2010). Indeed, a recent in vivo study showed that HS activates the Akt/mTOR signaling pathway in rat skeletal muscle (Yoshihara et al., 2013). However, it remains unclear whether the Akt/mTOR signaling pathway participates in the regulation of cell proliferation during HS.

The Langtang pig is an indigenous breed of south China that dominates the market in that region due to its earlier sexual maturity and better meat quality (Wang et al., 2012). Furthermore, compared with most commercial breeds of pigs, the Langtang pig has a stronger adaptive capacity in areas suffering from HS. In light of the crucial role of cell number and growth in determining skeletal muscle mass, the aim of this study was to determine whether the proliferation, apoptosis, and growth of Lantang swine skeletal muscle SCs are altered during HS.

\section{Materials and methods}

The study was conducted with approval and in accordance with the directives of the Institutional Animal Care and Use Committee of South China Agricultural University, Guangzhou, China.

\subsection{Cell culture and experimental design}

SCs were isolated from the longissimus dorsi muscles of new-born Lantang swine, so that the majority of the SCs were purified from fast-twitch muscles, and the resulting mononucleated cell preparations were prepared for immunocytochemical analysis using previously described procedures (Wang et al., 2012; Gao et al., 2015). SCs were grown serially in plastic culture flasks in Dulbecco's modified Eagle medium/nutrient mixture F-12 (DMEM/F-12) containing $10 \%$ fetal bovine serum (FBS). At confluence, cells were trypsinized and seeded in 96- or 6-well cell culture plates with approximately $1 \times 10^{4}$ or $5 \times 10^{4}$ cells/well, respectively, and maintained at $37^{\circ} \mathrm{C}$ in a $5 \% \mathrm{CO}_{2}$ incubator. After overnight $(24 \mathrm{~h})$ incubation, half of the cell culture plates were transferred to another incubator and maintained at $41{ }^{\circ} \mathrm{C}$ sustained $120 \mathrm{~h}$ for the duration of the HS research. The medium was changed every $2 \mathrm{~d}$. At least three independent experiments were performed to verify the results and the cells were isolated from a variety of piglets per replicate.

\subsection{Cell proliferation activity analysis}

SCs were seeded in 96- or 6-well cell culture plates with approximately $1 \times 10^{4}$ or $5 \times 10^{4}$ cells/well, respectively. The effects of HS on cell proliferation were determined by cell count assay and 3-(4,5dimethylthiazol-2-yl)-2,5-diphenyl tetrazolium bromide (MTT) method after treatment of 24, 48, 72, 96, and $120 \mathrm{~h}$. For MTT analysis, $20 \mu 15 \mathrm{mg} / \mathrm{ml}$ MTT (Sigma, St. Louis, MO, USA) solutions were added to each well and incubated for $4 \mathrm{~h}$. The plates were centrifuged at $1400 \mathrm{~g}$ for $15 \mathrm{~min}$ at $25{ }^{\circ} \mathrm{C}$, and the supernatants were carefully discarded. A total of $200 \mu \mathrm{l}$ DMSO working solution $(180 \mu \mathrm{l}$ DMSO plus $20 \mu \mathrm{l}$ $1 \mathrm{~mol} / \mathrm{L} \mathrm{HCl}$ ) were added to each well. The optical density (OD) value of the yellow reaction product was evaluated with an enzyme-linked immunosorbent assay (ELISA) reader at a wavelength of $490 \mathrm{~nm}$ $(n=20)$. For cell counting assay, 6-well cell culture plates were gently washed with phosphate buffered saline (PBS) and viable cells were counted using a hemocytometer under a light microscope $(n=6)$.

\subsection{Flow cytometry}

SCs were cultured in 6-well cell culture plates and cells were collected at 24,48 , and $72 \mathrm{~h}$, respectively, as previously described (Gao et al., 2015). 
Collected cells were fixed with $70 \%$ ice cold ethanol for cell cycle and cell size analysis, and cells were fixed with binding buffer for cell apoptosis analysis. For cell cycle analysis, the cells were centrifuged at $200 \mathrm{~g}$ for $10 \mathrm{~min}$ at $4{ }^{\circ} \mathrm{C}$, re-suspended in $1 \mathrm{ml} \mathrm{PBS}$, treated with $100 \mathrm{ml} 200 \mathrm{mg} / \mathrm{ml}$ DNase-free RNase A, and incubated at $37^{\circ} \mathrm{C}$ for $30 \mathrm{~min}$. Finally, the cells were treated with $100 \mu \mathrm{l} 50 \mu \mathrm{g} / \mathrm{ml}$ propidium iodide (PI) and incubated at room temperature $\left(25^{\circ} \mathrm{C}\right)$ for 10 min in the dark and subjected to flow cytometry using a Becton Dickinson FACScan (BD, Franklin Lake, NJ, USA). For cell size determination, fixed cells were washed twice with PBS and centrifuged at $200 \mathrm{~g}$ for $10 \mathrm{~min}$ at $4{ }^{\circ} \mathrm{C}$. Cell samples were then run on a Becton Dickinson FACScan. For cell apoptosis analysis, cells were mixed with $5 \mu$ annexin V-FITC before flow cytometric analysis. Then, $5 \mu \mathrm{l}$ of PI was added to cells and incubated at room temperature $\left(25{ }^{\circ} \mathrm{C}\right)$ for $10 \mathrm{~min}$ in the dark. Cell samples were finally run on a Becton Dickinson FACScan $(n=6)$.

\subsection{RNA isolation and quantitative reverse tran- scriptase polymerase chain reaction (qRT-PCR)}

Total RNA was isolated using the TRIzol reagent according to the manufacturer's instructions (Invitrogen, Carlsbad, CA, USA). The concentration and purity of the extracted total RNA were measured by spectrophotometric evaluation at 260 and $280 \mathrm{~nm}$ (Thermo Scientific, Waltham, MA, USA), and the RNA integrity was determined using $1 \%$ agarose gel electrophoresis. Quantitative real-time RT-PCR was performed using a Stratagene MxPro 3005P thermocycler (Agilent Technologies, Santa Clara, CA, USA) and one-step SYBR Green PCR Mix (TaKaRa, Dalian, China) according to optimized PCR protocols. Cycling conditions were: $95^{\circ} \mathrm{C}$ for $5 \mathrm{~min}$ followed by 40 cycles of $95^{\circ} \mathrm{C}$ for $30 \mathrm{~s}, 60^{\circ} \mathrm{C}$ for $30 \mathrm{~s}$, and $72{ }^{\circ} \mathrm{C}$ for 40 s. Glyceraldehyde-3-phosphate dehydrogenase $(G A P D H)$ was amplified in parallel with the target genes as a control, and each sample was analyzed 12 times. The relative mRNA expression level was calculated using $2^{-\Delta C_{\mathrm{T}}}\left(\Delta C_{\mathrm{T}}=C_{\mathrm{T}}\right.$ of target gene $-C_{\mathrm{T}}$ of GAPDH gene) method with a temperature of $37^{\circ} \mathrm{C}$ as the control $(n=6)$.

The primer sequences ( $5^{\prime}$ to $\left.3^{\prime}\right)$ were as follows: HSP70: GTG GCT CTA CCC GCA TCC C (forward) and GCA CAG CAG CAC CAT AGG C (reverse) and GAPDH: GGT CGG AGT GAA CGG ATT TG (forward) and CCT TGA CTG TGC CGT GGA AT (reverse).

\subsection{Western blot}

Cells were washed twice with PBS and then lysed on ice with lysis buffer $(50 \mathrm{mmol} / \mathrm{ml}$ Tris- $\mathrm{HCl}$, $\mathrm{pH} 7.5,150 \mathrm{mmol} / \mathrm{L} \mathrm{NaCl}, 1 \mathrm{mmol} / \mathrm{L}$ ethylenediaminetetraacetic acid (EDTA), $0.5 \%$ Triton X-100, $1 \mathrm{mmol} / \mathrm{L}$ phenylmethanesulfonyl fluoride (PMSF), and $1 \mathrm{mmol} / \mathrm{L} \mathrm{Na}_{3} \mathrm{VO}_{4}$ ) containing complete protease inhibitors (Invitrogen, Carlsbad, CA, USA). Subsequently, the samples were centrifuged at $12000 \mathrm{~g}$ for $5 \mathrm{~min}$ at $4{ }^{\circ} \mathrm{C}$ to remove insoluble debris, and the protein concentration was determined with the BCA Protein Assay Reagent Kit (Thermo Fisher Scientific, San Jose, CA, USA). The protein samples were boiled for $10 \mathrm{~min}$ and $15 \mu \mathrm{g}$ of lysates were subjected to $10 \%$ sodium dodecyl sulfate (SDS) gel electrophoresis following the manufacturer's instructions (SDS-PAGE gel kit; Beyotime, Jiangsu, China). Proteins were separated by electrophoresis at $80 \mathrm{~V}$ for $15 \mathrm{~min}$ and $110 \mathrm{~V}$ for 90 min using Tris-glycine running buffer $(0.025 \mathrm{mmol} / \mathrm{L}$ Tris base, $0.192 \mathrm{~mol} / \mathrm{L}$ glycine, and $0.1 \%$ SDS, pH 8.3), as described previously (Gao et al., 2015). Prestained molecular weight markers (Invitrogen, Carlsbad, CA, USA) were used to determine the molecular weight of proteins. After the electrophoresis was complete, the samples were transferred to polyvinylidene fluoride (PVDF) membranes at $100 \mathrm{~V}$ for 70 min using a transfer buffer containing $25 \mathrm{mmol} / \mathrm{L}$ Tris, $192 \mathrm{mmol} / \mathrm{L}$ glycine, and $10 \%$ methanol. The membranes were blocked for $2 \mathrm{~h}$ with Tris buffer solution (TBS) $(20 \mathrm{mmol} / \mathrm{L}$ Tris and $500 \mathrm{mmol} / \mathrm{L}$ $\mathrm{NaCl}, \mathrm{pH}$ 7.6) containing $5 \%$ bovine serum albumin (BSA) at room temperature, and then incubated overnight at $4{ }^{\circ} \mathrm{C}$ with primary antibodies. The membranes were washed 6 times for 5 min each with TBST buffer (TBS-buffered saline with Tween-20), and then incubated with the appropriate horseradish peroxidase-labeled secondary antibody for $2 \mathrm{~h}$ at room temperature. Finally, the proteins were visualized with the electrochemiluminescence (ECL)-plus chemiluminescence detection kit (Beyotime Institute of Biotechnology, Haimen, Nantong, China) in a FluorChem M system (Cell Biosciences, San Leandro, CA, USA), and the density of the bands was analyzed using ImageJ (http://rsb.info.nih.gov/ij). The protein values of HSP70, cleaved caspase-3, and eukaryotic initiation factor-4E (eIF4E) are presented as expression relative to the $\beta$-actin level in each lane, while the other protein values are presented with phosphorylation levels relative to the total level. The primary 
antibodies 1:1000 rabbit polyclonal antibody against Akt, 1:1000 rabbit polyclonal antibody against phospho-Akt $\left(\mathrm{Ser}^{473}\right), 1: 1000$ rabbit polyclonal antibody against mTOR, 1:1000 rabbit monoclonal antibody against phospho-mTOR (Ser $\left.{ }^{2448}\right), 1: 1000$ mouse monoclonal antibodies against S6K, 1:1000 rabbit polyclonal antibody against phospho-S6K $\left(\mathrm{Thr}^{389}\right)$, 1:1000 rabbit polyclonal antibody antiribosomal protein S6 (rpS6), 1:1000 rabbit polyclonal antibody against phospho-rpS6 (Ser $\left.{ }^{235 / 236}\right), 1: 1000$ rabbit polyclonal antibody against 4EBP1, and 1:1000 rabbit polyclonal antibody against phospho-4EBP1 $\left(\mathrm{Thr}^{70}\right)$ were purchased from Cell Signaling Technology (Beverly, MA, USA). 1:800 mouse monoclonal antibody against eIF4E (sc-9976) and 1:800 rabbit polyclonal antibody against cleaved caspase-3 (sc-7148) were purchased from Santa Cruz (Dallas, TX, USA). 1:1000 mouse monoclonal antibodies against HSP70 (MB0105) and anti- $\beta$-actin were purchased from Bioworld (Louis Park, MN, USA). The second antibodies, anti-rabbit and anti-mouse IgG, were purchased from Beijing Biosynthesis Biotechnology (Tongzhou, Beijing, China) $(n=4)$.

\subsection{Statistical analysis}

Values are expressed as mean \pm standard error of mean (SEM). Comparisons between groups were performed using an independent samples $t$-test using
SAS Version 9.2 (SAS Institute Inc., Cary, NC, USA) with statistical significance assumed when $P<0.05$.

\section{Results}

\subsection{Heat shock response}

To determine whether the SCs cultured at $41{ }^{\circ} \mathrm{C}$ suffered from HS, the HSP70 mRNA and protein levels were assessed using qRT-PCR and Western blotting, respectively. As predicted, the HSP70 mRNA and protein expression levels were significantly increased $(P<0.05)$ at $41{ }^{\circ} \mathrm{C}$ (Fig. 1). These results indicate that the temperature used is sufficient to induce a heat shock response in Lantang swine SCs.

\subsection{Cell proliferation and cell growth}

To evaluate the effects of HS on the proliferation of Lantang swine SCs, cell counting and MTT assays were conducted, and the results are shown in Figs. 2a and $2 \mathrm{~b}$. Our results indicate that HS stimulated swine SC proliferation $(P<0.05)$ within $24 \mathrm{~h}$, and there was no difference between the control and HS groups at $48 \mathrm{~h}(P>0.05)$. Compared with the control group, the SC number was decreased in the HS group beginning at $72 \mathrm{~h}$ after treatment $(P<0.05)$; the results of the MTT assay were the same as those of cell counting, which reveal that continuous HS (72 h) effectively
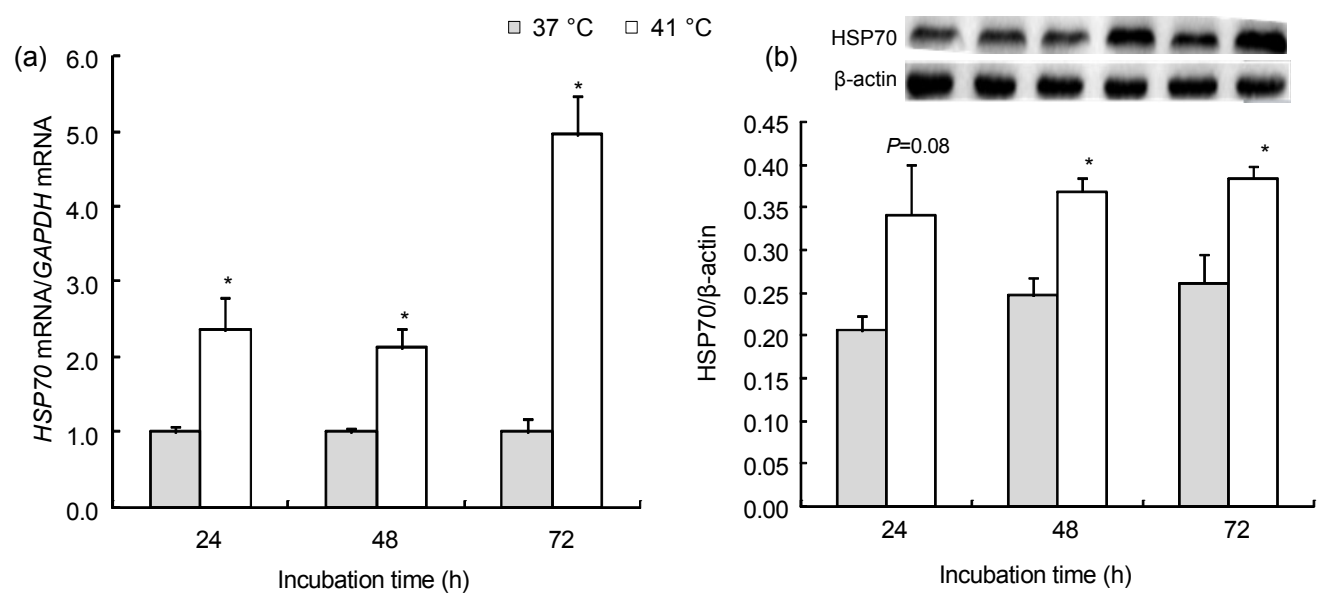

Fig. 1 Heat shock protein 70 (HSP70) messenger RNA (mRNA) and protein expression level in Lantang swine satellite cells with or without heat stress (HS)

After pre-incubation at $37^{\circ} \mathrm{C}$ for $24 \mathrm{~h}$, the incubator temperature of the HS group was increased to $41{ }^{\circ} \mathrm{C}$ and that of the control group was maintained at $37^{\circ} \mathrm{C}$. (a) Relative quantity of $H S P 70$ mRNA $(n=6)$. The vertical axis represents the target gene threshold cycle $\left(C_{\mathrm{T}}\right)$ corrected for GAPDH. (b) The expression level of HSP70 protein was measured by Western blot, and $\beta$-actin was used as an internal control $(n=4)$. The data represent the means \pm SEM. ${ }^{*} P<0.05$, HS treatment vs. the control. The results are representative of three separate experiments 

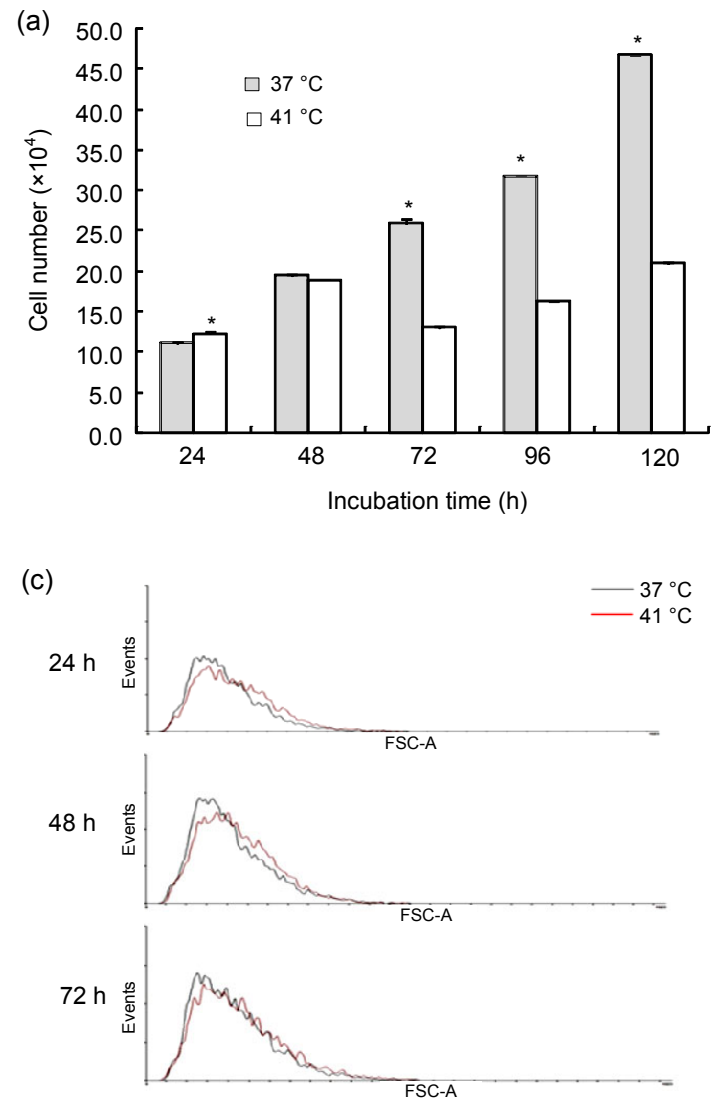
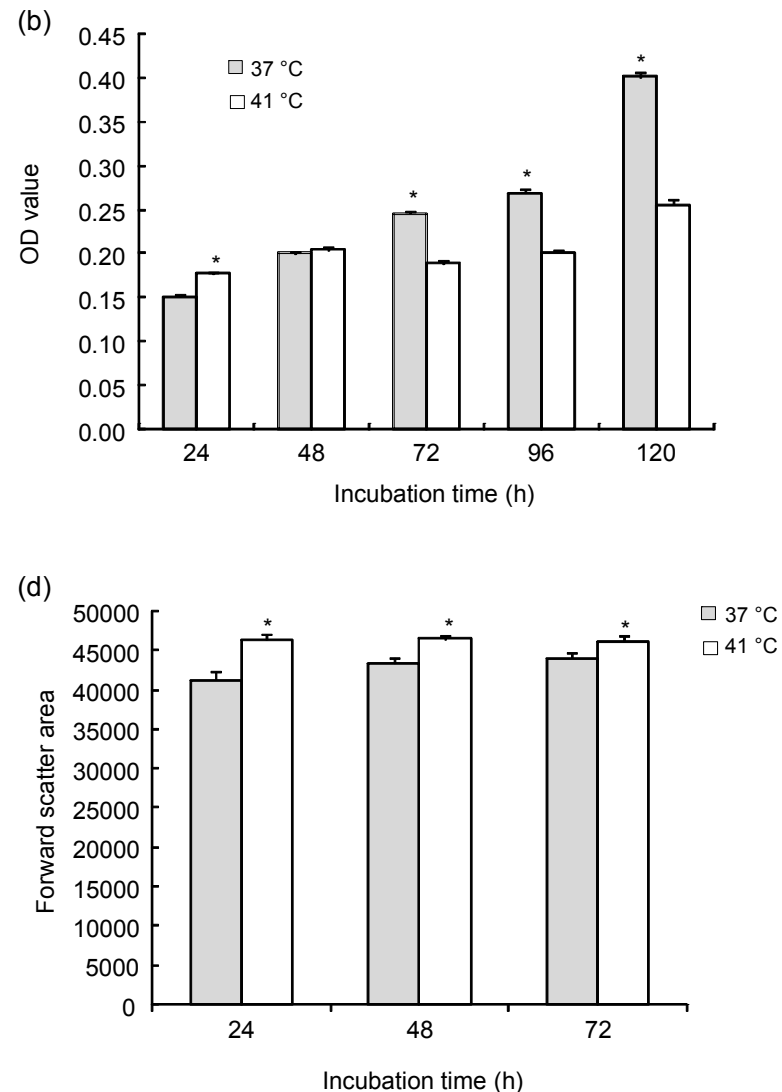

Fig. 2 Effect of heat stress (HS) on the proliferation and growth of Lantang swine satellite cells (SCs) After pre-incubation at $37^{\circ} \mathrm{C}$ for $24 \mathrm{~h}$, the incubator temperature of HS group was increased to $41{ }^{\circ} \mathrm{C}$ and that of the control group was maintained at $37^{\circ} \mathrm{C}$. Cell numbers were determined using the cell count $(n=6)$ (a) and MTT ( $\left.n=20\right)$ (b) assays at the indicated time after HS. (c, d) Cell size was determined with flow cytometry at the indicated time $(n=6)$. The data represent the means \pm SEM. ${ }^{*} P<0.05$, HS treatment vs. the control. The results are representative of three separate experiments

inhibits the proliferation of SCs. According to the proliferation results, we selected a heating time of 24 to $72 \mathrm{~h}$ to elucidate the effect of HS on SC growth. Cell size distribution was measured by flow cytometry (FCM; Fig. 2c), which show that HS unexpectedly increased the SC size $(P<0.05)$ compared with the control group (Fig. 2d). A similar result was also found by hematoxylin-eosin staining (data not shown). These results demonstrated that HS suppresses SC proliferation and promotes $\mathrm{SC}$ growth.

\subsection{Cell cycle and apoptosis}

It has been well established that cell division is regulated by the cell cycle, and accumulating evidence has revealed that HS inhibits cell proliferation mainly via G0/G1 and G2/M arrest (Kühl and Rensing, 2000). Therefore, we reasoned that the effect of heat on the proliferation of Lantang swine SCs is cell- cycle related. The phase distribution was monitored with FCM, and the DNA content distribution of the cells consisted of two predominant peaks corresponding to cells in the G0/G1 and G2/M phases and an intermediate region between both peaks contained cells in the $\mathrm{S}$ phase of the cell cycle (Fig. 3a). From our results, we observed a decrease in the percentage of cells in the G0/G1 phase $(P<0.05$; Fig. $3 \mathrm{~b})$ and an increase in the percentage of cells in the $\mathrm{S}$ phases $(P<0.05$; Fig. 3c). Furthermore, the percentage of cells in the $\mathrm{G} 2 / \mathrm{M}$ phase (Fig. 3d) decreased at $48 \mathrm{~h}$ $(P<0.05)$, whereas the percentage of cells increased at $72 \mathrm{~h}(P<0.05)$. In addition to cell cycle arrest, apoptosis is another factor that affects cell number; thus, to investigate this further, our apoptosis analysis revealed that $\mathrm{HS}$ significantly increased $(P<0.05)$ apoptosis and the expression of cleaved caspase-3 $(P<0.05)$ in Lantang swine SCs at 72 h (Fig. 4). 
(a)
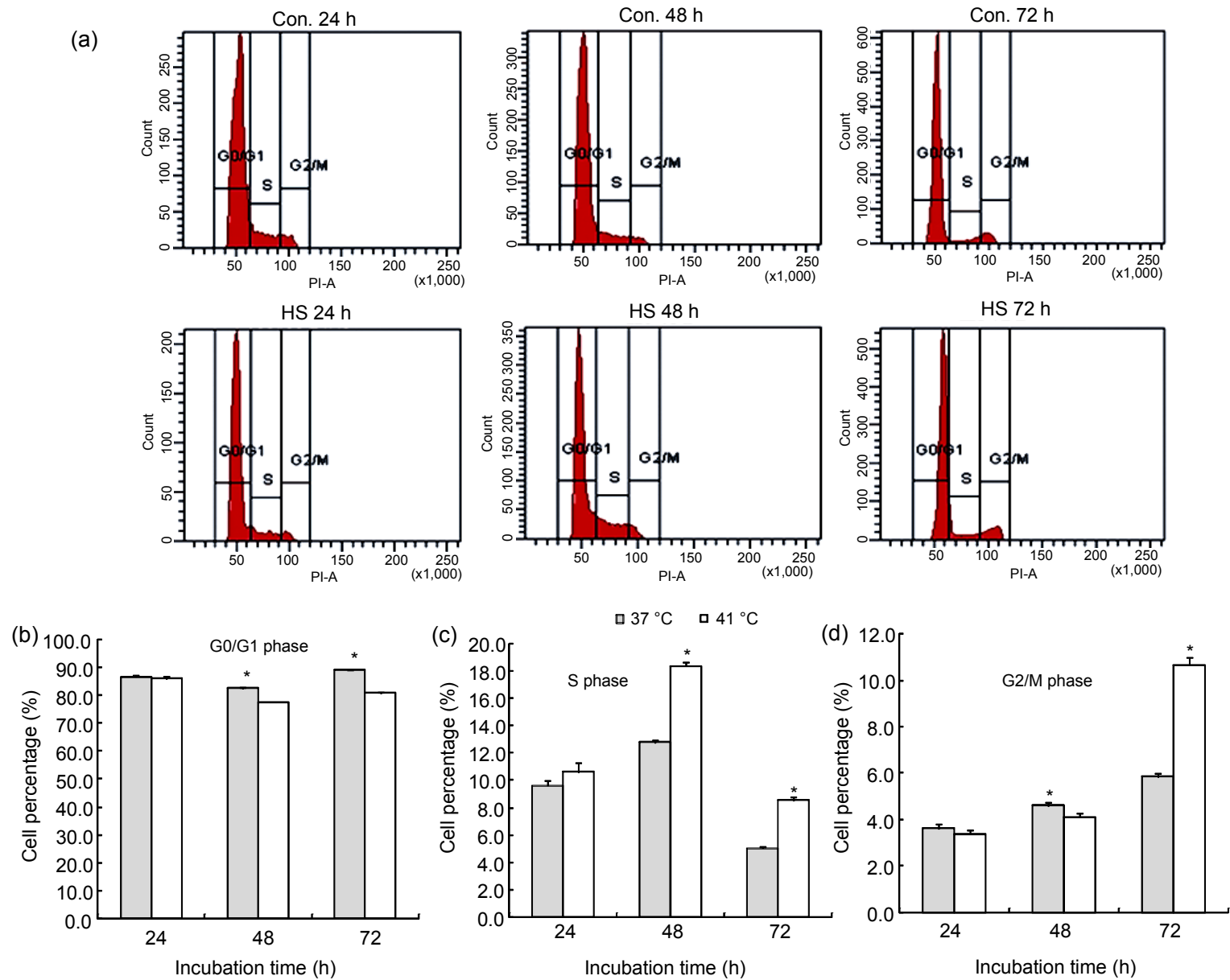

Fig. 3 Analysis of cell cycle distribution in Lantang swine satellite cells (SCs)

After pre-incubation at $37^{\circ} \mathrm{C}$ for $24 \mathrm{~h}$, the incubator temperature of the heat stress (HS) group was increased to $41{ }^{\circ} \mathrm{C}$ and that of the control group was maintained at $37^{\circ} \mathrm{C}$. (a) The distribution of phase was monitored using flow cytometry $(n=6)$. The two prominent peaks represent cells in the $\mathrm{G} 0 / \mathrm{G} 1$ and $\mathrm{G} 2 / \mathrm{M}$ phases, and the intermediate region between peaks represents the S phase cells. Percentages of cells in G0/G1 (b), S (c), and G2/M (d) phases were detected in flow cytometry analyses at the indicated time. The data represent the means \pm SEM. ${ }^{*} P<0.05$, HS treatment vs. the control. The results are representative of three separate experiments

\subsection{Signaling responses}

Considering the importance of the mTOR pathway for regulating cell proliferation, growth, and apoptosis, the phosphorylation ratios of mTOR pathway components are shown in Fig. 5. The total protein expression levels, with the exception of Akt, were decreased at $72 \mathrm{~h}$, and there was no statistically significant change in mTOR, S6K, rpS6, or 4EBP1 after HS (data not shown). We found that the phosphorylation ratios of Akt $\left(\mathrm{Ser}^{473}\right)$, S6K $\left(\mathrm{Thr}^{389}\right)$, and rpS6 $\left(\operatorname{Ser}^{235 / 236}\right)$ were significantly higher $(P<0.05)$ in the HS than in the control group within $72 \mathrm{~h}$, but no significant difference $(P>0.05)$ was found for $\mathrm{p}-4 \mathrm{EBP} 1$
$\left(\mathrm{Thr}^{70}\right)$ and eIF4E. HS significantly $(P<0.05)$ upregulated the p-mTOR $\left(\operatorname{Ser}^{2448}\right)$ phosphorylation ratio within $48 \mathrm{~h}$, but there was no significant difference $(P>0.05)$ at $72 \mathrm{~h}$.

\section{Discussion}

An HS response will be induced in organisms that have been exposed to HS. Studies of a number of species, tissues, and cells have shown that the HS response results in the accumulation of HSPs (Lindquist, 1986; Welch, 1992). The effects of HS are 

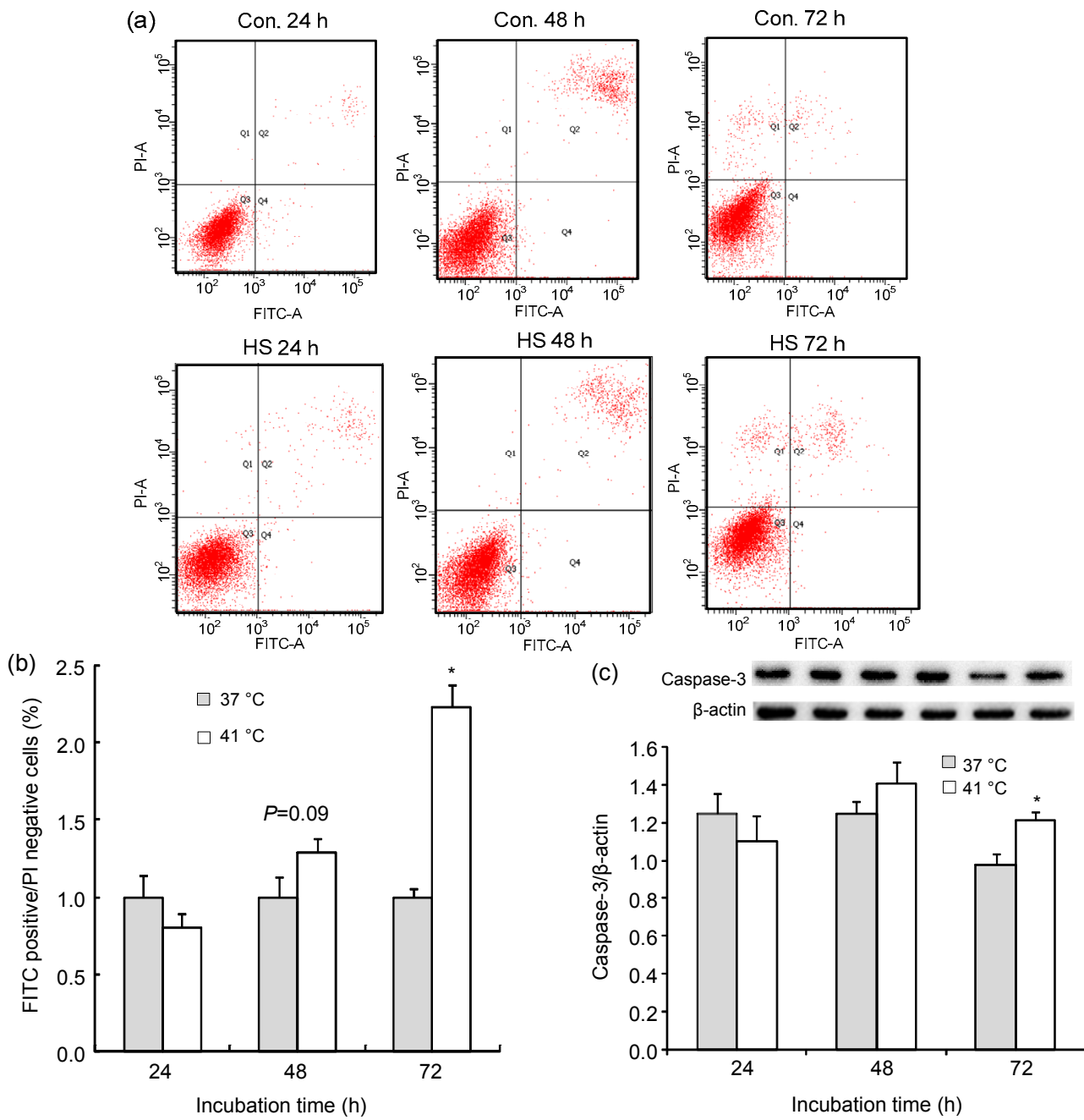

Fig. 4 Induction of apoptosis in Lantang swine satellite cell (SC) cultures after heat stress (HS)

After pre-incubation at $37^{\circ} \mathrm{C}$ for $24 \mathrm{~h}$, the incubator temperature of the HS group was increased to $41{ }^{\circ} \mathrm{C}$ and that of the control group was maintained at $37^{\circ} \mathrm{C}$. Typical histograms (a) and profiles (b) of HS-induced apoptosis was determined by AnV-FITC/PI staining after HS exposure and FCM analysis $(n=6)$. (c) The expression of cleaved caspase- 3 was determined by Western blot and $\beta$-actin was used as an internal control. The data represent the means \pm SEM. ${ }^{*} P<0.05$, HS treatment vs. the control. The results are representative of three separate experiments

affected by the intensity and duration of HS since the long processing HS time or the high setting HS temperature can easily led to death of cells. Therefore, given that our treatment lasted for $120 \mathrm{~h}$, we have chosen $41{ }^{\circ} \mathrm{C}$ for the HS-inducing temperature, which is approximately $1{ }^{\circ} \mathrm{C}$ above the core body temperature of swine $\left(39.3-39.6{ }^{\circ} \mathrm{C}\right)$ and within the range of rectal temperatures observed in studies of heatstressed swine (Liu et al., 2009). Increases in the HSP70 mRNA and protein level indicated that the temperature used in this study was sufficient to induce an HS response in swine SCs, which is consistent with Kamanga-Sollo et al. (2011).
The proliferative ability of SCs was measured using cell counting and MTT assay over a short period of $120 \mathrm{~h}$. Our results showed that HS could inhibit SC proliferation and the inhibition was much more severe when the treating time was prolonged. These results are consistent with the view that effects of HS are determined by the duration and intensity of the temperature. Furthermore, cell cycle progression and cell growth interact with each other to sustain the proliferative response, and sustained proliferative responses are supported by continuous cell division ( $\mathrm{Li}$ et al., 2014) and stress response pathways often evoke cell cycle arrest to avoid the distribution of damaged 


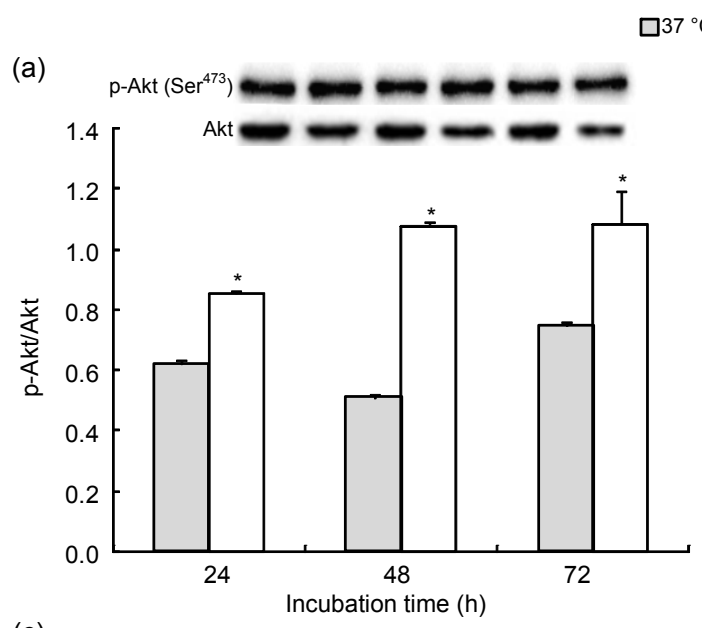

$\square 41^{\circ} \mathrm{C}$

(c)

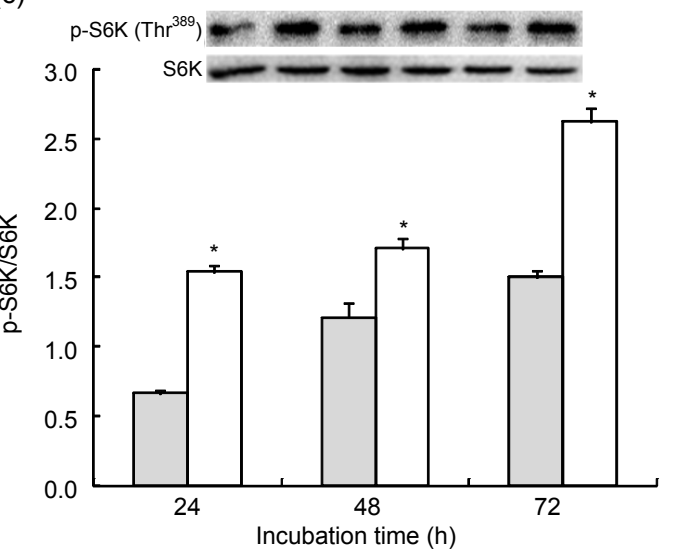

(b)

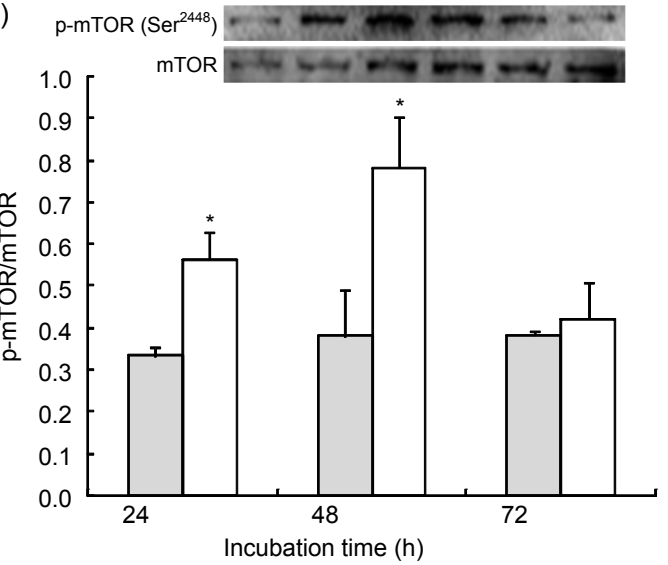

(d)

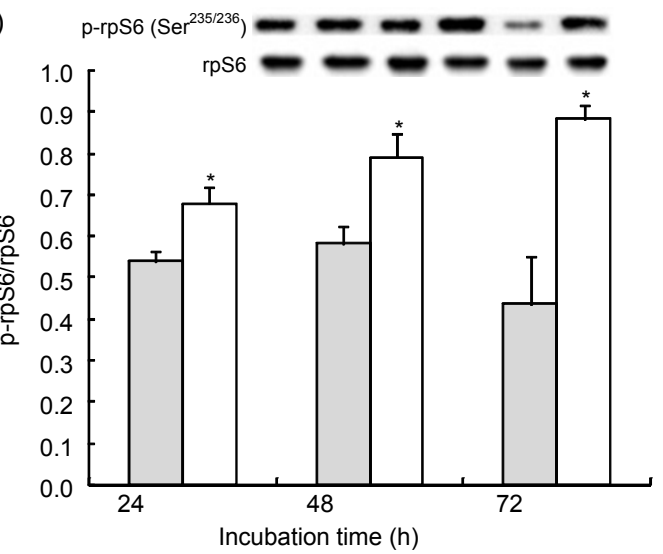

(e)

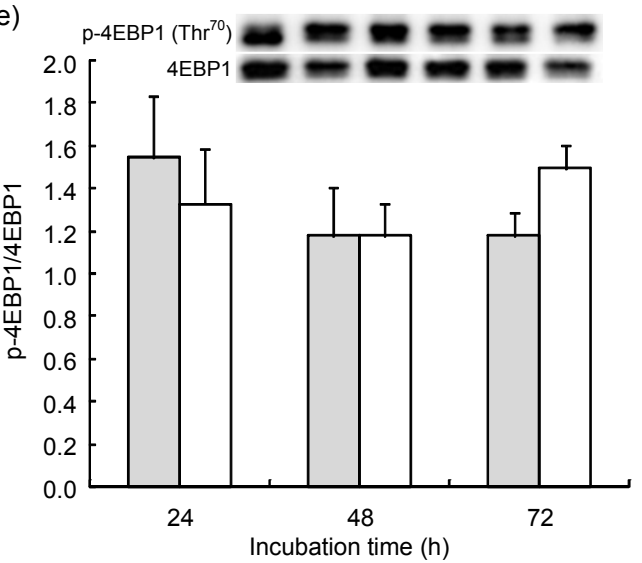

(f)

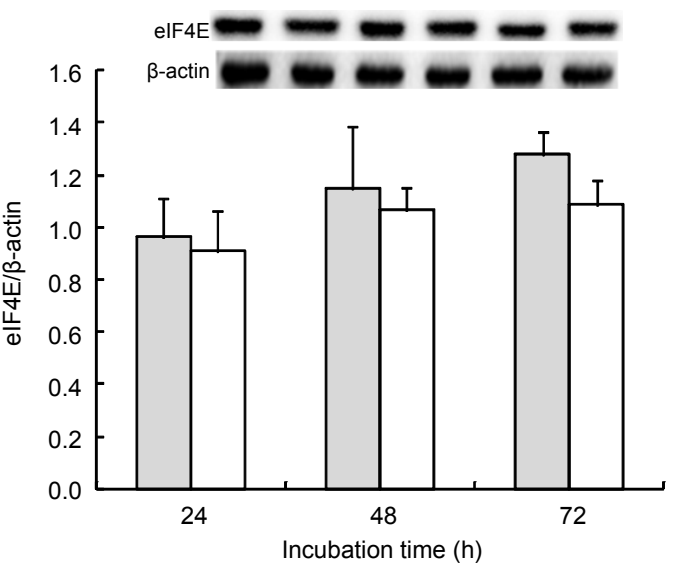

Fig. 5 Expression of mammalian target of rapamycin (mTOR) pathway regulators in Lantang swine satellite cell (SC) cultures after heat stress (HS) $(n=4)$

After pre-incubation at $37^{\circ} \mathrm{C}$ for $24 \mathrm{~h}$, the incubator temperature of the HS group was increased to $41{ }^{\circ} \mathrm{C}$ and that of the control group maintained at $37^{\circ} \mathrm{C}$. The values of protein kinase b (Akt) (a), mTOR (b), ribosomal protein S6 kinase (S6K) (c), ribosomal protein S6 (rpS6) (d), and 4E binding protein 1 (4EBP1) (e) are presented with phosphorylation levels relative to the total level in each line, while the values of eukaryotic initiation factor-4E (eIF4E) (f) are presented as expression relative to the $\beta$-actin level. The data represent the means \pm SEM. ${ }^{*} P<0.05$, HS treatment vs. the control. The results are representative of three separate experiments 
macromolecules, leading to proliferation inhibition (Costa et al., 2011). In addition, DNA damage is caused by both exogenous and endogenous agents resulting in different types of lesion. These lesions are then recognized by components of the different repair mechanisms. Cells always change the cell cycle distribution to deal with the stresses because these repair processes can take some time to complete. To understand how proliferation is controlled under HS, SCs were tested for DNA content after 24, 48, and $72 \mathrm{~h}$ of proliferation to determine the distribution of cells in the G0/G1, S, and G2/M phases of the cell cycle. The results showed that the percentage of cells in the G0/G1 phase decreased significantly but the percentage of cells in the $\mathrm{S}$ phase became significantly higher after HS than that observed in the control group. Interestingly, although the percentage of cells in the $\mathrm{G} 2 / \mathrm{M}$ phase was significantly lower at $48 \mathrm{~h}$, it was higher at $72 \mathrm{~h}$ after HS. These results are in accordance with Bang et al. (2000)'s observation that $15 \mathrm{~min}$ of HS increases the percentage of cells in the $\mathrm{G} 2 / \mathrm{M}$ phase. We speculate that HS induced the DNA damage and ultimately led to cell cycle progress arrest. Heat shock sensitivity itself is cell cycle phase dependent, and various studies demonstrated that cells in S phase or mitosis are more sensitive to high temperatures than those in G1 or G2 phases (Velichko et al., 2013). There is also evidence that heat stress leads to a transient arrest of cells at mainly two cell cycle checkpoints, the G1/S and G2/M transitions (Furusawa et al., 2012). Because the $\mathrm{PI} 3 \mathrm{~K} / \mathrm{Akt} / \mathrm{mTOR}$ pathway has been proven to play a predominant role in cell cycle progression, we surmised that the change in the cell cycle distribution might be due to a change in the activation of the PI3K/Akt/mTOR pathway. $\mathrm{Li}$ Y. et al. (2012) have shown that decreases in the activity of the Akt/mTOR pathway inhibit cell proliferation by inducing $\mathrm{G} 2 / \mathrm{M}$ arrest. Our data showed that although HS increased the Akt and mTOR phosphorylation ratio, the discrepancy in the mTOR phosphorylation ratio disappeared at $72 \mathrm{~h}$. In combination with the increase in the $\mathrm{G} 2 / \mathrm{M}$ phase, these results support the hypothesis that HS disrupts the cell cycle. In contrast with the recent report that 4EBPs control mTORC1-mediated cell proliferation (Dowling et al., 2010), the 4EBP1 phosphorylation ratio was indistinguishable from that of the control cells, and these results are supported by the study of rat skeletal muscle under HS (Yoshihara et al., 2013), which showed that HS activates the Akt/mTOR signaling pathway while the phosphorylation of 4EBP1 was shown to be similar among groups of rats in both the soleus and plantaris muscles. Thus, our data might indicate that the HS-mediated perturbation of SC cycle kinetics and reduction in SC proliferation are independent of 4EBP1 status. Furthermore, the SC proliferation may be dependent upon several other factors, including paired box 7, myogenic factor 5, myogenin, myostatin, etc. However, more studies are needed to support this speculation.

Cell growth and cell proliferation are clearly separable processes. Cell growth defines the mass accumulation or the size increase, and how cells control their size under various conditions is a fundamental open question (Taheri-Araghi et al., 2015). Highly dynamic cells can maintain their size for life but can also grow or shrink, requiring robust but adaptable controls, and the loss of the control can lead to a series of diseases (Lloyd, 2013). Our results demonstrate that HS significantly increased the SC size. As far as we know, this is the first study of HS effects on SCs growth. The PI3K/Akt/mTORC1 pathway has been shown to be a major regulator of cell growth through its downstream S6K1 rather than its S6K2 (Pende et al., 2004). Our results illustrate that HS altered the mTOR phosphorylation ratio of $\operatorname{Ser}^{2448}$ within $48 \mathrm{~h}$. However, the phosphorylation ratio was indistinguishable from that of the control cells at $72 \mathrm{~h}$. Combined with the change in the phosphorylation ratio of Akt, our results indicate that HS activated the Akt/mTOR signaling pathway. Despite the fact that there was no significant difference in 4EBP1, another downstream target of mTOR, the S6K phosphorylation ratio, increased after HS and S6K activation and this was confirmed by the phosphorylation of its substrate S6 ribosomal protein. In fact, Uehara et al. (2004) has shown that HS induced a significant increase in $\mathrm{p}$-S6K expression after heat exposure at $41{ }^{\circ} \mathrm{C}$. Thus, the results suggest that HS promotes SC growth via the Akt/mTOR/S6K pathway.

In addition to cell cycle arrest, apoptosis is another factor that determines cell number. Kühl and Rensing (2000) have indicated that cellular sensitivity to hyperthermia depends on the cell cycle stage and that cells in the $\mathrm{S}$ phase are more sensitive to 
death-inducing conditions. Our results showed that HS increased cell number in $24 \mathrm{~h}$ and decreased the cell number in $72 \mathrm{~h}$. Therefore, we speculate that apoptosis may play an important role in the decrease of the number of SCs. As expected, the results reveal increases in the apoptosis percentage and expression of cleaved caspase- 3 at $72 \mathrm{~h}$, which is consistent with Shelton et al. (2010). Although Akt has been shown to prevent HS-induced cell death, the HS-mediated Akt phosphorylation ratio increased in a way that is consistent with that found in the study of Yoshihara et al. (2013) rather than that found in the study of Bang et al. (2000). In contrast, the increase in the Akt phosphorylation ratio was inconsistent with the fact that HS induced apoptosis at $72 \mathrm{~h}$. There may be several factors other than Akt involved in SC apoptosis. Furthermore, it is possible that the increase in the Akt phosphorylation ratio in the HS treatment group may have been, at least partly, responsible for limiting massive SC death during this period. However, the relationship between Akt expression and SC death is pending investigation. In addition to indicating an HS response, HSP70 plays a crucial role in adjusting the proliferation of cells that have been exposed to stress, which may explain the increase in cell number at $24 \mathrm{~h}$. However, in conditions of continuous stress (HS for $72 \mathrm{~h}$ ), cellular defense mechanisms are insufficient to cope with the excessive stress, leading to induced apoptosis and a decrease in cell number. Taken together, this study indicates that short-term HS assists significantly in the promotion of SC proliferation and long-term HS decreases the number of SCs by suppressing proliferation and inducing apoptosis.

\section{Conclusions}

This study demonstrate that HS suppresses SC proliferation and induces apoptosis to decrease the number of cells. The main finding of this study is that HS promotes SC growth via the $\mathrm{Akt} / \mathrm{mTOR} / \mathrm{S} 6 \mathrm{~K}$ pathway.

\section{Compliance with ethics guidelines}

Chun-qi GAO, Yin-ling ZHAO, Hai-chang LI, Wei-guo SUI, Hui-chao YAN, and Xiu-qi WANG declare that they have no conflict of interest.

All institutional and national guidelines for the care and use of laboratory animals were followed.

\section{References}

Bang, O.S., Ha, B.G., Park, E.K., et al., 2000. Activation of Akt is induced by heat shock and involved in suppression of heat-shock-induced apoptosis of NIH3T3 cells. Biochem. Biophys. Res. Commun., 278(2):306-311. [doi:10. 1006/bbrc.2000.3805]

Costa, M.R., Ortega, F., Brill, M.S., et al., 2011. Continuous live imaging of adult neural stem cell division and lineage progression in vitro. Development, 138(6):1057-1068. [doi:10.1242/dev.061663]

Dowling, R.J., Topisirovic, I., Alain, T., et al., 2010. mTORC1-mediated cell proliferation, but not cell growth, controlled by the 4E-BPs. Science, 328(5982):1172-1176. [doi:10.1126/science.1187532]

Furusawa, Y., Iizumi, T., Fujiwara, Y., et al., 2012. Inhibition of checkpoint kinase 1 abrogates $\mathrm{G}_{2} / \mathrm{M}$ checkpoint activation and promotes apoptosis under heat stress. Apoptosis, 17(1):102-122. [doi:10.1007/s10495-011-0660-7]

Gao, C.Q., Zhi, R., Yang, Z., et al., 2015. Low dose of IGF-I increases cell size of skeletal muscle satellite cells via Akt/S6K signaling pathway. J. Cell Biochem., in press. [doi:10.1002/jcb.25212]

Kamanga-Sollo, E., Pampusch, M.S., White, M.E., et al., 2011. Effects of heat stress on proliferation, protein turnover, and abundance of heat shock protein messenger ribonucleic acid in cultured porcine muscle satellite cells. $J$. Anim. Sci., 89(11):3473-3480. [doi:10.2527/jas.20114123]

Kühl, N.M., Rensing, L., 2000. Heat shock effects on cell cycle progression. Cell Mol. Life Sci., 57(3):450-463. [doi:10. 1007/PL00000707]

Li, C.M., Yan, H.C., Fu, H.L., et al., 2014. Molecular cloning, sequence analysis, and function of the intestinal epithelial stem cell marker Bmi1 in pig intestinal epithelial cells. $J$. Anim. Sci., 92(1):85-94. [doi:10.2527/jas.2013-7048]

Li, S.Q., Li, R.F., Xi, S.M., et al., 2012. Systematical analysis of impacts of heat stress on the proliferation, apoptosis and metabolism of mouse hepatocyte. J. Physiol. Sci., 62(1):29-43. [doi:10.1007/s12576-011-0183-6]

Li, Y., Zhang, P., Qiu, F., et al., 2012. Inactivation of PI3K/ Akt signaling mediates proliferation inhibition and $\mathrm{G} 2 / \mathrm{M}$ phase arrest induced by andrographolide in human glioblastoma cells. Life Sci., 90(25-26):962-967. [doi:10. 1016/j.lfs.2012.04.044]

Lindquist, S., 1986. The heat-shock response. Annu. Rev. Biochem., 55:1151-1191. [doi:10.1146/annurev.bi.55.070 186.005443]

Liu, F., Yin, J., Du, M., et al., 2009. Heat-stress-induced damage to porcine small intestinal epithelium associated with down regulation of epithelial growth factor signaling. J. Anim. Sci., 87(6):1941-1949. [doi:10.2527/jas.20081624]

Lloyd, A.C., 2013. The regulation of cell size. Cell, 154(6): 1194-1205. [doi:10.1016/j.cell.2013.08.053]

Locke, M., Celotti, C., 2014. The effect of heat stress on skeletal muscle contractile properties. Cell Stress Chaperones, 
19(4):519-527. [doi:10.1007/s12192-013-0478-z]

Millward, D., Garlick, P., Nnanyelugo, D., et al., 1976. The relative importance of muscle protein synthesis and breakdown in the regulation of muscle mass. Biochem. J., 156(1):185-188.

Morales, A., Grageola, F., Garcia, H., et al., 2014. Performance, serum amino acid concentrations and expression of selected genes in pair-fed growing pigs exposed to high ambient temperatures. J. Anim. Physiol. Anim. Nutr., 98(5):928-935. [doi:10.1111/jpn.12161]

Pearce, S.C., Gabler, N.K., Ross, J.W., et al., 2013. The effects of heat stress and plane of nutrition on metabolism in growing pigs, J. Anim. Sci., 91(5):2108-2118. [doi:10. 2527/jas.2012-5738]

Pende, M., Um, S.H., Mieulet, V., et al., 2004. S6K1 $1^{(--)} /$ $\mathrm{S} 6 \mathrm{~K} 2^{(--)}$mice exhibit perinatal lethality and rapamycinsensitive 5'-terminal oligopyrimidine mRNA translation and reveal a mitogen-activated protein kinase-dependent S6 kinase pathway. Mol. Cell Biol., 24(8):3112-3124. [doi:10.1128/mcb.24.8.3112-3124.2004]

Rezai Rad, M., Wise, G.E., Brooks, H., et al., 2013. Activation of proliferation and differentiation of dental follicle stem cells (DFSCs) by heat stress. Cell Prolif., 46(1):58-66. [doi:10.1111/cpr.12004]

Shelton, S.N., Dillard, C.D., Robertson, J.D., 2010. Activation of caspase-9, but not caspase-2 or caspase-8, is essential for heat-induced apoptosis in Jurkat cells. J. Biol. Chem., 285(52):40525-40533. [doi:10.1074/jbc.M110.167635]

Sirotkin, A.V., Bauer, M., 2011. Heat shock proteins in porcine ovary: synthesis, accumulation and regulation by stress and hormones. Cell Stress Chaperones, 16(4): 379-387. [doi:10.1007/s12192-010-0252-4]

Taheri-Araghi, S., Bradde, S., Sauls, J.T., et al., 2015. Cellsize control and homeostasis in bacteria. Curr. Biol., 25(3):385-391. [doi:10.1016/j.cub.2014.12.009]

Tumaneng, K., Russell, R.C., Guan, K.L., 2012. Organ size control by hippo and tor pathways. Curr. Biol., 22(9): R368-R379. [doi:10.1016/j.cub.2012.03.003]

Uehara, K., Goto, K., Kobayashi, T., et al., 2004. Heat-stress enhances proliferative potential in rat soleus muscle. Jpn. J. Physiol., 54(3):263-271. [doi:10.2170/jjphysiol.54.263]

Velichko, A.K., Markova, E.N., Petrova, N.V., et al., 2013. Mechanisms of heat shock response in mammals. Cell Mol. Life Sci., 70(22):4229-4241. [doi:10.1007/s00018013-1348-7]
Wang, X.Q., Yang, W.J., Yang, Z., et al., 2012. The differential proliferative ability of satellite cells in Lantang and landrace pigs. PLoS ONE, 7(3):e32537. [doi:10.1371/ journal.pone.0032537]

Welch, W.J., 1992. Mammalian stress response: cell physiology, structure/function of stress proteins, and implications for medicine and disease. Physiol. Rev., 72(4): 1063-1081.

Yoshihara, T., Naito, H., Kakigi, R., et al., 2013. Heat stress activates the Akt/mTOR signalling pathway in rat skeletal muscle. Acta Physiol., 207(2):416-426. [doi:10.1111/ apha.12040]

Zhang, M., Jiang, M., Bi, Y., et al., 2012. Autophagy and apoptosis act as partners to induce germ cell death after heat stress in mice. PLoS ONE, 7(7):e41412. [doi:10. 1371/journal.pone.0041412]

\section{中文概要}

题 目: 热应激对猪骨骼肌卫星细胞增殖和生长的影响

目 的: 探究热应激对蓝塘猪骨骼肌卫星细胞增殖与生长 的影响, 分析其作用机制。

创新点: 通过体外细胞模型研究了热应激对猪骨骼肌卫星 细胞增殖与生长的影响, 发现热应激通过 $\mathrm{Akt} / \mathrm{mTOR} / \mathrm{S} 6 \mathrm{~K}$ 途径调控细胞的生长。

方 法: 本试验选用 1 日龄蓝塘猪背最长肌的骨骼肌卫星 细胞, 对照组为 $37{ }^{\circ} \mathrm{C}$ 正常培养, 热应激组培养 温度为 $41{ }^{\circ} \mathrm{C}$, 其它培养条件相同。采用细胞计 数、MTT 法、流式细胞术等手段分析比较热应激 对蓝塘猪骨骼肌卫星细胞增殖与生长的影响; 利 用实时逆转录聚合酶链式反应 (RT-PCR) 和蛋白 质印迹法 (Western blot) 等方法, 检测了热休克 蛋白 HSP70、半胱氨酸蛋白酶-3 (caspase-3) 及 哺乳动物雷帕霉素靶蛋白 (mTOR) 信号通路关 键基因的表达。

结 论: (1) $41{ }^{\circ} \mathrm{C}$ 热处理可引起蓝塘猪骨骼肌卫星细胞 产生热应激反应; (2) 热应激 $72 \mathrm{~h}$ 会通过改变细 胞周期、抑制细胞增殖并诱导细胞调亡等共同作 用减少细胞数目; (3) 热应激通过 $\mathrm{Akt} / \mathrm{mTOR} / \mathrm{S} 6 \mathrm{~K}$ 途径调控细胞的生长。

关键词: 热应激; 蓝塘猪; 细胞增殖; 细胞生长; 调亡; $\mathrm{Akt} / \mathrm{mTOR} / \mathrm{S} 6 \mathrm{~K}$ 信号通路 